VISNYK LVIV UNIV.

ерія геогр. 2011. ип. 39. . 22-27

Ser. Geogr. 2011. N 39. P. $22-27$

631. 445.4:631.415.2(210.7)(2625)(477.74)

\author{
- іл нчин, . ошуренко, • відерськ \\ деський н ціон льний університет імені . . ечников , \\ вул. ворянськ, 2, дес, 65082, кр їн
}

ро н лізов но результ ти вивчення речовинно-хімічного скл ду і вл стивостей чорноземних грунтів о. міїний, зокрем , пок зники кислотно-основної х р ктеристики. исловлено думку про визн ч льну роль у формув нні скл ду і вл стивостей грунтів остров т їхньої кислотності, зокрем , вихідних геологічних порід (конгломер тів, конглобрекчій, пісковиків) екстр кислого силік тно-хімічного скл ду.

лючові слов : острів міїний, чорноземні грунти, грунтов кислотність, хімічний скл д порід.

оширення кислих грунтів з звич й пов'яз не з певними біоклім тичними умов ми їхнього утворення. йч стіше це грунти під деревною рослинністю в гумідних чи супергумідних умов х н нек рбон тних пород х, з звич й, кислого хімічного скл ду підзолисті, буроземи, червоноземи т ін. жерелом кислотності цих грунтів є орг нічні т мінер льні кислоти, продукти життєдіяльності орг нізмів і мікроорг нізмів т розкл д ння їхніх решток, т кож кислі виділення ктивних коренів деревної рослинності $[4,5,10,12,13,15$ т ін.]. одноч с п нує думк , що в ридних і семи ридних біоклім тичних умов х утворюються грунти з нейтр льною і лужною ре кцією. о них тр диційно з числяють чорноземи степових зон світу $[3,4,13]$ т суходолу півдня кр їни [14, с. 105-119].

езульт ти вперше проведених н ми грунтово-генетичних досліджень н о. міїний у 2003-2008 рр. з свідчили специфічність як генетичної природи сформов них тут чорноземних грунтів, т к і їхнього речовинно-хімічного скл ду т вл стивостей $[1,2]$. роцес чорноземоутворення н острові відбув ється н ділянк х м лопотужного к м'янисто-щебенюв того нек рбон тного елювію чи елюво-делювію щільних порід кислого хімічного скл ду (конгломер тів, конглобрекчій, пісковиків), рідше строк токолірних глин під степовою різнотр вно-зл ковою рослинністю. ормуються ці грунти в умов х пр ктично постійного ер льно-імпульвериз ційного принесення солей з кв торії орного моря. хньою особливістює м л потужність профілю (н леж ть до неповнорозвинених і короткопрофільних чорноземів 3 потужністю гумусового горизонту $H q+H p q$ до 25 і 25-45 см, відповідно), нек рбон тність, сильн щебенюв тість, висок гумусність, пр ктичн безструктурність 3 добре вир женої мікро грегов ності, кислотність ( ч сто і сильн кислотність) грунтового середовищ, що не вл стиво типово чорноземним грунт м суходолу півдня кр їни. огляду н це в процесі дослідження речовинно-хімічного скл ду і вл стивостей чорноземних грунтів о. міїний визн чено пок зники їхньої кислотності, що д є змогу висловити певні міркув ння щодо природи кислотності цих грунтів.

(C) іл нчин ., ошуренко ., відерськ ., 2011 
відібр них грунтових зр зк х з генетичних горизонтів по профілю досліджув них чорноземних грунтів, поряд із з г льноприйнятими л бор торними н ліз ми (гр нулометричний скл д, вміст гумусу, легкорозчинних солей, обмінно-поглинутих к тіонів т елементів живлення), визн ч ли т кі пок зники кислотності грунтів:

- ре кція грунтового розчину (p водне і $\mathrm{p}$ сольової витяжки);

- кислотність обмінн з методом йкух $\mathrm{p}$;

- люміній рухомий (обмінний) 3 околовим;

- кислотність гідролітичн з ппеном.

ведені у т бл. 1 результ ти дослідження чорноземних грунтів о. міїний з свідчують специфічність (і н віть унік льність) їхнього речовинно-хімічного скл ду і вл стивостей, зокрем стосовно кислотності грунтового середовищ . прикл д, $\mathrm{p}$ водне у верхніх горизонт х пересічної більшості досліджув них грунтів у меж х 5,0-6,0 з в ріюв нням від 4,6 до 6,1. н чення р сольової витяжки у перев жній більшості верхніх горизонтів цих грунтів у меж х 4,0-5,5 з в ріюв нням від 3,4 до 6,0 і н віть 6,4-6,6 3 умов господ рського окультурення. цими пок зник ми, згідно з [6, с. 42], перев жн більшість грунтів остров м є кислу т сильнокислу ре кцію. глибиною по профілю кислотність зрост є - у перев жній більшості до сильнокислого ступеня зі зн ченнями $\mathrm{p}$ вод $4,0-4,5, \mathrm{p}$ сол $3,2-3,6$.

блиця 1

еякі результ ти н літичного дослідження чорноземних грунтів остров міїний

\begin{tabular}{|c|c|c|c|c|c|c|c|c|c|c|c|}
\hline \multirow[t]{2}{*}{ 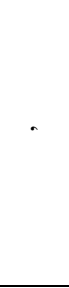 } & \multirow[t]{2}{*}{ 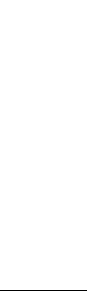 } & \multirow[t]{2}{*}{ 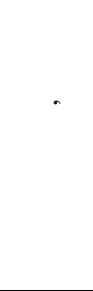 } & \multirow{2}{*}{ 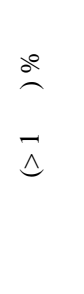 } & 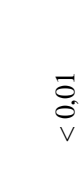 & 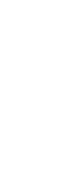 & \multirow[t]{2}{*}{ 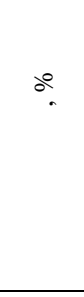 } & \multirow[t]{2}{*}{ 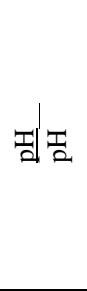 } & 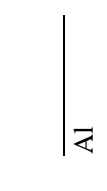 & 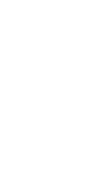 & 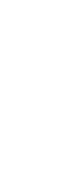 & 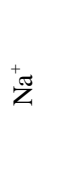 \\
\hline & & & & \multicolumn{2}{|c|}{$\begin{array}{l}\text { \% від м си } \\
\text { дрібнозему } \\
\text { (< } 1 \text { мм) }\end{array}$} & & & \multicolumn{4}{|c|}{ ммоль/100 г грунту } \\
\hline \multirow{3}{*}{-2 , } & $\mathrm{Hq}$ & $6-16$ & 71,5 & 15,6 & 14,86 & 0,093 & $\frac{4,65}{3,45}$ & $\frac{0,86}{0,76}$ & 29,43 & 17,71 & 2,02 \\
\hline & Hpq & $16-24$ & 72,9 & 22,4 & 13,17 & 0,092 & $\frac{4,45}{3,50}$ & $\frac{1,96}{1,83}$ & 31,27 & 13,11 & 1,84 \\
\hline & Phq & $30-40$ & 83,3 & 19,3 & 9,96 & 0,088 & $\frac{4,50}{3,45}$ & $\frac{1,42}{1,31}$ & 22,08 & \multicolumn{2}{|c|}{ е визн ч ли } \\
\hline \multirow{3}{*}{$\mathrm{K}^{-4}$} & $\mathrm{Hq}$ & $10-20$ & 73,6 & 36,1 & 8,23 & 0,090 & $\frac{5,95}{5,10}$ & $\frac{0,10}{0,04}$ & 8,50 & 27,04 & 1,10 \\
\hline & $\mathrm{Hq}(\mathrm{Fs})$ & $35-45$ & 31,6 & 38,4 & 8,95 & 0,067 & $\begin{array}{l}5,18 \\
3,96 \\
\end{array}$ & $\begin{array}{l}0,18 \\
0,09\end{array}$ & 16,46 & 18,27 & 0,66 \\
\hline & $\mathrm{P}(\mathrm{h}) \mathrm{q}$ & $55-65$ & 48,9 & 38,9 & 3,61 & 0,052 & $\frac{5,18}{4,45}$ & $\frac{0,14}{0,05}$ & 9,64 & \multicolumn{2}{|c|}{ е визн ч ли } \\
\hline \multirow{2}{*}{$\mathrm{K}^{-5,}$} & $\mathrm{Hq}$ & $5-15$ & 65,5 & 31,9 & 11,72 & 0,105 & $\frac{5,30}{4,35}$ & $\frac{0,16}{0,06}$ & 16,20 & 20,44 & 1,40 \\
\hline & Hpq & $25-35$ & 65,8 & 25,8 & 8,35 & 0,081 & $\frac{5,48}{4,25}$ & $\frac{0,16}{0,07}$ & 15,42 & 21,51 & 1,89 \\
\hline \multirow[t]{2}{*}{-7} & $\mathrm{Hq}$ & $7-17$ & 70,0 & 20,3 & 13,17 & 0,087 & $\frac{5,15}{4,30}$ & $\frac{0,26}{0,18}$ & 23,21 & 26,36 & 1,59 \\
\hline & Hpq & $20-30$ & 73,8 & 27,2 & 9,15 & 0,080 & $\frac{4,17}{3,60}$ & $\frac{0,50}{0,40}$ & 28,56 & 15,20 & 1,16 \\
\hline-8 & $\mathrm{Hq}$ & $3-13$ & 59,9 & 14,7 & 14,12 & 0,069 & $\frac{4,58}{4,05}$ & $\frac{0,50}{0,38}$ & 24,88 & 31,59 & 1,16 \\
\hline
\end{tabular}


кінчення т бл. 1

\begin{tabular}{|l|l|l|l|l|l|l|l|l|l|l|l|}
\hline & Нрq & $14-24$ & 83,5 & 25,2 & 12,73 & 0,054 & $\frac{4,33}{3,45}$ & $\frac{1,46}{1,33}$ & 34,60 & 14,38 & 0,62 \\
\cline { 2 - 12 } & Phq & $28-38$ & 76,7 & 20,1 & 10,10 & 0,092 & $\frac{4,57}{3,52}$ & $\frac{0,63}{0,53}$ & 29,35 & \multicolumn{2}{|c|}{ е визн ч ли } \\
\hline \multirow{3}{*}{-9,} & Нq & $5-12$ & 64,0 & 21,0 & 8,51 & 0,136 & $\frac{5,70}{4,95}$ & $\frac{0,18}{0,00}$ & 6,48 & 25,06 & 0,90 \\
\cline { 2 - 12 } & Нpq & $12-22$ & 62,6 & 35,5 & 9,32 & 0,128 & $\frac{4,47}{4,02}$ & $\frac{0,75}{0,18}$ & 16,56 & 24,69 & 2,19 \\
\cline { 2 - 12 } & Phq & $30-40$ & 71,8 & 39,3 & 3,93 & 0,135 & $\frac{4,05}{4,00}$ & $\frac{2,91}{1,18}$ & 16,64 & е визн ч ли \\
\hline-10, & Нq & $11-21$ & 78,8 & 18,1 & 11,88 & 0,166 & $\frac{6,08}{5,50}$ & $\frac{0,09}{0,01}$ & 6,22 & 36,12 & 1,20 \\
\cline { 2 - 12 } & Нрq & $24-34$ & 78,6 & 26,5 & 10,52 & 0,259 & $\frac{4,93}{4,80}$ & $\frac{0,15}{0,07}$ & 17,34 & 21,39 & 0,50 \\
\hline
\end{tabular}

р и м і т к : ндекси грунтів: - чорнозем неповнорозвинений; - чорнозем короткопрофільний.

p ктично ідентичними є результ ти визн чення і потенційної кислотності досліджув них грунтів - як її обмінної, т к і гідролітичної скл дової. бмінн кислотність у верхніх горизонт х пересічно невисок (0,1-0,5 ммоль/100 г грунту), що корелює 3 вищими зн ченнями в цих горизонт х р сольової витяжки. онизу по профілю грунтів зн чення обмінної кислотності суттєво, ч сто й різко зрост ють, відповідно до зменшення зн чень $\mathrm{p}$ сол, досяг ючи м ксимуму в перехідному горизонті $p q$ т в грунтотворній породі. кщо у верхніх горизонт х обмінн кислотність зумовлен головно -іон ми, причому основним їхнім джерелом $є$, ймовірно, орг нічні кислоти включно з гумусовими $[10,13]$, то донизу - зі зменшенням вмісту гумусу суттєво і н віть різко у величині обмінної кислотності зрост є ч стк обмінного люмінію (див. т бл. 1). езвично висок в досліджув них грунт х і гідролітичн кислотність, зн чення якої зіст вні хіб що з гідролітичною кислотністю сильнокислих бурих лісових грунтів pп т [14, с. 154-155]. бсолютні зн чення цієї форми потенційної кислотності у верхніх горизонт х змінюються від 3-6 до 9 ммоль/100 г грунту в умов х кислої і сл бкокислої ре кції до 23-29 ммоль/100 г в умов х сильнокислої ре кції (розрізи -2, 7, 8 т ін.). онизу по профілю досліджув них грунтів гідролітичн кислотність зрост є. е однозн чно свідчить про те, що головною причиною кислотності чорноземних грунтів остров $є$ вихідні м теринські породи, точніше - їхній кислий хімічний скл д.

ля підтвердження чи з перечення цього висновку звернемось до результ тів визн чення хімічного скл ду геологічних порід остров (т бл. 2).

блиця 2

езульт ти силік тного н лізу порід о. міїний, з [9]

\begin{tabular}{|c|c|c|c|c|c|c|c|c|c|c|c|}
\hline \multirow{2}{*}{$\mathrm{p}$ зок } & \multirow{2}{*}{ ород } & \multicolumn{10}{|c|}{ міст елементів, \% } \\
\hline & & $\mathrm{Si}$ & $\mathrm{Ti}$ & $\mathrm{Al}$ & $\mathrm{Fe}$ & $\mathrm{Mn}$ & $\mathrm{Mg}$ & $\mathrm{Ca}$ & $\mathrm{Na}$ & K & $P$ \\
\hline $12-5$ & в рцит & 96,0 & 0,07 & 1,16 & 0,82 & 0,01 & 0,04 & 0 & 0 & 0,31 & 0,01 \\
\hline $12-11$ & $\begin{array}{l}\text { ісковик } \\
\text { кв рцито- } \\
\text { вий }\end{array}$ & 95,6 & 0,08 & 2,28 & 0,49 & 0,01 & 0,2 & 0,1 & 0 & 0,5 & 0,11 \\
\hline $12-8$ & ісковик & 97,5 & 0,05 & 1,05 & 1,55 & 0,01 & 0,07 & 0 & 0 & 0,17 & 0,06 \\
\hline $13-12$ & в рцит & 98,3 & 0,05 & 0,74 & 0,04 & 0,01 & 0,08 & 0,09 & 0 & 0,24 & 0,09 \\
\hline $13-1$ & $\begin{array}{r}\text { онгло- } \\
\text { брекчія } \\
\end{array}$ & 97,1 & 0,04 & 0,86 & 0,53 & 0,01 & 0,02 & 0,38 & 0 & 0,11 & 0,58 \\
\hline
\end{tabular}


к 3 свідчують н ведені у т бл. 2 д ні, вміст кремнекислоти в пород х остров досяг є 96-98\% від їхньої м си. цим пок зником це супер- чи екстр кислі породи, оскільки кислими вв ж ють [8, с. 144] породи з вмістом $\mathrm{SiO}_{2}$ пон д $65 \%$. одноч с у в ловому хімічному скл ді порід містяться в мізерній кількості, ч сто їх зовсім нем , лужні т лужноземельні хімічні елементи. окрем, нем н трію, ч сто і к льцію (у пісковик х). оновий вміст к льцію і м гнію в пород $\mathrm{x}-\mathrm{H}$ рівні сотих ч сток відсотК , причому вміст м гнію з звич й більший. осить низький т кож в ловий вміст у пород х люмінію т $з$ ліз .

оловний висновок з результ т ми в лового хімічного н лізу геологічних порід остров як вихідної м теринської породи для грунтоутворення: н т ких кислих чи екстр кислих пород х, згідно з теорією грунтотворення [4, 10, 13 т ін.], формуються з звич й кислі т сильнокислі грунти. прикл д: н кислих пород х різної генези т йгово-лісової зони івнічної вропи т хідноєвропейської рівнини сформув лись кислі т сильнокислі грунти підзолистого типу грунтоутворення [3, 4 т ін.], елюво-делювії кислих гірських порід рп т утворилися буроземи 3 екстр кислою кту льною і потенційною кислотністю [5, 14]. ислу ре кцію м ють т кож червоноземи, жовтоземи т червоно-жовті фер літні грунти вологих лісових обл стей субтропічних і екв торі льно-тропічних широт н кислих фер літних кор х звітрюв ння [3, 4], чорноземоподібні грунти н нек рбон тних пород х під високотр вними преріями субборе льного поясу івнічної мерики й хідної зії т червонясто-чорні грунти субтропічних прерій івнічної і івденної мерики н фер літизов них кислих пород $\mathrm{x}[3,4]$.

ік вими у пл ні з лежності вл стивостей грунтів від вихідних грунтотворних порід є відомі з грунтозн вчо-геогр фічної літер тури $[3,4,14]$ прикл ди: у хідній і ентр льній вропі, рп т х т риму, поряд із бурозем ми з кислою ре кцією н кислих м теринських пород $\mathrm{x}$, широко тр пляються буроземи зі сл бколужною і н віть лужною ре кцією грунтового середовищ н основних і к рбон тних пород х.

ведені вище прикл ди суттєвої з лежності кислотно-основних вл стивостей грунтів від хімізму грунтотворних порід д ють підст ви стверджув ти, що вихідні грунтотворні породи в н шому вип дку, точніше - їхній екстр кислий хімічний скл д, визн ч ють специфіку речовинно-хімічного скл ду і вл стивостей сформов них н них чорноземних грунтів, у тому числі й незвично високу їхню кислотність, що посилюється з глибиною по профілю. риблизно т ку ж думку висловив л ндш фтозн вець . щенко: силік тний (хімічно кислий - . .) скл д порід остров обумовлює н лежність с мих цих порід і сформов них н них л ндш фтних комплексів до кл су кислих л ндш фтів [11, с. 55]. о цього висновку можн дод ти про н лежність і сформов них н цих пород х грунтів як компонент л ндш фтних комплексів остров до кл су кислих.

о речі, н логічну думку свого ч су висловив . окуч єв у основоположній роботі з теорії чорноземоутворення “ усский чернозем” [7]. численних прикл д х і ф кт х він довів, що чорноземи утворюються н н йрізном нітніших пород $\mathrm{x}$ : лес $\mathrm{x}$ i лесоподібних суглинк х і глин х, в лунних і безв лунних глин х, суглинк х і супіск х, в пняк х і мергелях, глинистих сл нцях т інших щільних пород х, почин ючи від девонського до постпліоценового віку. дн к будов, скл д $і$ вл стивості чорноземів суттєво відрізняються з лежно від породи (виділено н ми), н якій вони утворились.

тже, викл дені вище результ ти дослідження природи кислотності чорноземних грунтів о. міїний т н ліз одерж них д них д ють підст ви зробити т кі основні висновки. 
1. р ктично н всій території о. міїний чорноземні грунти м ють кислу ре кцію. ричому донизу по профілю зн чення кту льної і потенційної кислотності досліджув них грунтів зрост $є$.

2. ірогідно, визн ч льну роль у формув нні специфічного речовинно-хімічного скл ду і вл стивостей чорноземних грунтів остров т кислотності їх, зокрем , відігр ють вихідні геологічні породи остров , точніше - екстр кислий хімічний скл д цих порід.

3. жерел ми -іонів у досліджув них грунт х остров , вірогідно, є орг нічні кислоти і кислі продукти виділень ктивних коренів степової тр в'яної рослинності. жерелом же рухомого люмінію в грунт х, ймовірно, $\epsilon$ люміній крист лічних гр ток первинних і вторинних мінер лів, що перебув ють н різних ст діях протолізу, вн слідок чого н явний у них люміній може бути витіснений у грунтовий розчин і ст ти першопричиною кислотності цих грунтів.

одноч с вв ж ємо, що викл дені вище м тері ли дослідження природи кислотності чорноземних грунтів остров міїний є попередніми і потребують под льшого вивчення і уточнення.

1. іл нчин . . ро генетичну природу чорноземів о. міїний, їх речовинно-хімічного скл ду $і$ вл стивостей / . . іл нчин, . . ошуренко, . . відерськ // існик дес. ун-ту. ер. геогр. т геол. н уки. 2009. . 14. ип. 1. . 240-245.

2. іл нчин . . мови формув ння т генетичні особливості грунтів остров міїний / . . iл нчин, . . н лт й, . . ортик, . . уяновський // ричорномор. екол. бюл. 2006. № 3, 4. .1. . 89-101.

3. $л$ зовск я . . очвы з рубежных стр н : еогр фия почв и сельскохозяйственное использов ние / . . л зовск я. . : ысль, 1975. 351 с.

4. $л$ зовск $я$. . еогр фия почв с основ ми почвоведения : чебник / . . л зовск я, . . енн диев. . : зд-во оск. ун-т , 1995. 400 с.

5. оголев . . урые горно-лесные почвы оветских рп т/ . . оголев : исс.... д-р сель.-хоз. н ук. ьвов : , 1965. 484 с.

6. ордієнко . . снови грунтозн вств і землеробств : ідручник/ . . ордієнко, . . едвиг , . . с дчий, . . сінній. . : енікс, 2000. 390 с.

7. окуч ев . . усский чернозем : тчет ольн. экон. об-ву // . . окуч ев. збр. соч. . 1. . : ельхозгиз, 1948. . 28-480.

8. елінський . . г льн геологія : урс лекцій / . . елінський, . . риж нівськ . дес : стропринт, 2001. - 168 с.

9. иук . . итология и мет морфизм скл дч того фунд мент кифской плиты в предел х кр инского ерноморья / . . цук. : исс.... к нд. геол. н ук. десс : , 1997. 141 с.

10. рлов . . имия почв : чебник / . . рлов. . : зд-во оск. ун-т , 1985. 376 с.

11. щенко . . стрів міїний. рирод, мешк нці, землеустрій: оногр фія / . . щенко. : 2008. $140 \mathrm{c}$

12. етербургский . . грохимия и физиология пит ния р стений / . . етербургский. . . оссельхозизд т, $1970.334 \mathrm{c}$

13. очвоведение. очв и почвообр зов ние / [под ред. . . овды, . . оз нов ] / [ . . елицин , . . сильевск я, . . . ришин и др.]. . . ысш. шк., 1988. . 1.400с.

14. рирод кр инской . очвы / [ . ерн ндер, . . оголев, . . ов лишин и др]. иев: ук. думк , 1986. 216 с.

15. ернов . . природе почвенной кислотности / . . . ернов. . . : зд-во

$186 \mathrm{c}$. 


\title{
THE NATURE OF CHORNOZEM SOILS ACIDITY OF ZMIINY ISLAND
}

\author{
Ya. Bilanchyn, L. Goshurenko, I. Sviderska
}

Odessa state agrarian university, Kanatna St., 9, UA - 65039 Odessa, Ukraine

Results of substantive and chemical investigation of Zmiiny island chornozem soils as well as their peculiarities, based on acid characteristics, are analyzed. Opinion is expressed about a main role in forming island soils consistence and acidity peculiarities of their basic geological constructions (conglomerates, conglobrectias, sand rock) of extra-acid silicate composition.

Key words: Zmiiny island, chornozem soils, soil acidity, chemical rock composition.

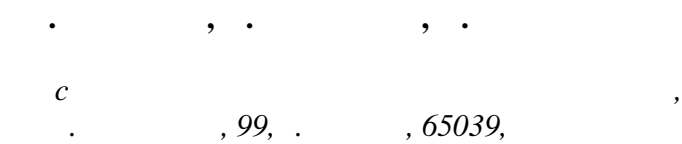

ро н лизиров ны результ ты изучения вещественно-химического сост в и свойств черноземних почв о. меинный, в ч стности, пок з тели кислотно-основной х р ктеристики. ыск 3 но мнение о определяющей роли в формиров нии сост в и свойств почв остров и их кислотности, в ч стности, исходных геологических пород (конгломер тов, конглобрекчий, песч ников) экстр кислого силик тно-химического сост в .

лючевые слов : остров меинный, черноземные почвы, почвенн я кислотность, химический сост в пород.

т ття н дійшл до редколегії 11.10.2009

рийнят до друку 16.11.2010 